\title{
PERANCANGAN DAN IMPLEMENTASI SISTEM CHAMBER UNTUK PENGUJIAN ENERGI EFISIENSI LEMARI PENDINGIN
}

\section{Design and Implementation Chamber System for Refrigerator Energy Efficiency Testing}

\author{
Prayoga Bakti ${ }^{1}$ dan Pranoto H. Rusmin ${ }^{2}$ \\ ${ }^{1}$ Pusat Penelitian Sistem Mutu dan Teknologi Pengujian - LIPI \\ Kawasan PUSPIPTEK gedung 417, Setu, Tangerang Selatan, Indonesia 15314 \\ 2Sekolah Teknik Elektro dan Informatika - Institut Teknologi Bandung \\ Jl. Ganesha No.10, Bandung, Jawa Barat, Indonesia \\ e-mail: prayogabakti@gmail.com
}

Diterima: 6 November 2017, Direvisi: 9 April 2018, Disetujui: 10 April 2018

\begin{abstract}
Abstrak
Standar IEC 62552-1:2015 mengatur mengenai pengujian energi efisiensi untuk lemari pendingin, terdapat persyaratan mengenai kondisi lingkungan pengujian. Salah satu spesifikasi suhu yang diinginkan oleh standar adalah $32{ }^{\circ} \mathrm{C}$ dengan toleransi $\pm 0,5^{\circ} \mathrm{C}$. Dirancang suatu ruangan khusus (chamber) yang mampu mengkondisikan suhu sesuai standar. Sistem pada chamber memiliki aktuator tunggal berupa pemanas udara yang dikendalikan menggunakan microcontroller. Metode pengendali PID dan fuzzy dirancang pada penelitian ini dan akan dibandingkan satu dengan lainnya. Tujuan perancangan dan implementasi pengendali fuzzy adalah untuk mempercepat waktu tunak suhu pada sistem chamber. Pengendali fuzzy memiliki respon lebih baik dibandingkan pengendali PID dengan kemampuan mencapai keadaan tunak sebesar 690 detik, lebih cepat 90 detik dari PID. Adapun kedua pengendali memiliki kesalahan (error) yang masih dalam batas toleransi yang diizinkan.
\end{abstract}

Kata kunci: standar, IEC, pengujian, pengendali, suhu.

\section{Abstract}

The IEC 62552-1: 2015 standard regulates the testing of energy efficiency for refrigerators, there is a requirement regarding the conditions of the test environment. One of the desired temperature specifications by the standard is $32{ }^{\circ} \mathrm{C}$ with a tolerance of $\pm 0.5^{\circ} \mathrm{C}$. It has been designed a special room (chamber) that is able to conditioned the temperature according to the standard. The chamber system has a single actuator in the form air heater that controlled by a microcontroller. PID and fuzzy control methods are designed in this research and will be compared. The purpose of designing and implementing fuzzy controllers is to speed up the steady-state temperature on the chamber system. The fuzzy controller has a better response than the PID controller with the ability to achieve steady state in 690 seconds, 90 seconds faster than PID. The two controllers have errors that are within tolerable limits.

Keywords: standard, IEC, testing, controller, temperature.

\section{PENDAHULUAN}

\subsection{Latar Belakang}

Indonesia sejak tahun 2009 sudah mulai program energi efisiensi dengan mengikuti program BRESL (Barriers Removal to the cost effective development of Energy Efficiency Standards and Labelling). Program tersebut merupakan kerjasama pemerintah Indonesia dengan UNDP (United Nations Development Programe). Pelatihan dan pengenalan standar uji telah dilakukan terhadap beberapa produk seperti lemari pendingin, AC, kipas angin, penanak nasi dan lampu swa-ballast. Salah satu produk yang akan di buat mandatory (diwajibkan) adalah pengujian labelisasi energi untuk lemari pendingin (id.undp, 2016).

Standar uji IEC 62552-1 untuk pengujian lemari pendingin telah terbit tahun 2015, memuat tentang kriteria pengujian untuk lemari pendingin termasuk labelisasi energi efisiensi. Salah satu kriteria yang terdapat dalam standar adalah suhu ambient yang harus dikondisikan pada suhu yang sudah ditentukan (IEC, 2015). Hal ini membutuhkan ruangan yang dapat dikondisikan suhunya (chamber). Tidak semua laboratorium uji di Indonesia memiliki chamber sesuai dengan standar, untuk memenuhi hal tersebut 
membutuhkan dana yang cukup besar. Mahalnya harga chamber dikarenakan spesifikasi chamber yang cukup tinggi bahkan melebihi standar uji. Oleh karena itu diperlukan penelitian mengenai chamber yang sesuai dengan standar uji namun memiliki harga yang murah.

Tujuan dari penelitian ini adalah untuk mendesain dan membuat prototipe sistem climatic chamber yang sesuai dengan standar uji IEC 62552-1. Penelitian mengenai metode pengendali juga dilakukan untuk mendapatkan sistem dengan suhu yang dapat dikendalikan sesuai dengan spesifikasi standar yaitu toleransi kesalahan $\pm 0,5^{\circ} \mathrm{C}$. Adapun batasan penelitian ini adalah sistem mampu menghasilkan parameter suhu yang dikendalikan pada suhu acuan $32{ }^{\circ} \mathrm{C}$.

\section{TINJAUAN PUSTAKA}

\subsection{Prinsip Kerja Chamber}

Environtmental test chamber merupakan alat yang digunakan untuk memastikan keandalan dari produk-produk industri, khususnya elektronik melalui serangkaian pengujian parameter lingkungan seperti suhu yang berkelanjutan. Chamber tersebut mampu menyediakan suhu panas atau dingin yang dilengkapi dengan alatalat ukur baik analog maupun digital untuk melengkapi hasil pengujian. Saat ini sudah banyak perusahaan-perusahaan yang membuat dan menghasilkan chamber untuk pengujian dengan beragam standar (Globalspec, 2016).

Komponen mekanis utama dari suatu chamber untuk pengujian energi efisiensi lemari pendingin ditunjukkan gambar 1 (Hermes dkk, 2012). Terdapat ruangan chamber (test section) untuk menempatkan benda uji (lemari pendingin) yang dilengkapi dengan pintu (door). Di bagian bawah terdapat evaporator yang berfungsi untuk mendinginkan suhu udara yang mengalir melaluinya. Terdapat humidifier yang berfungsi memberikan kelembaban untuk ruangan chamber. Fans memiliki fungsi sebagai pendorong aliran udara sehingga tercipta sirkulasi secara berkesinambungan. Heaters merupakan elemen pemanas untuk memanaskan udara yang akan dialirkan kedalam chamber.

Prinsip kerja dari chamber berdasarkan gambar 2 adalah dengan memberikan aliran udara yang di trigger oleh kipas (fans). Aliran udara yang tercipta kemudian akan melalui pemanas (heater) dan akan naik suhunya. Udara yang sudah dipanaskan kemudian dimasukkan kedalam ruang uji (test section) melalui bagian atas. Setelah memenuhi bagian test section, udara akan keluar melalui bagian bawah dan akan terdorong menuju evaporator. Pada bagian ini udara akan didinginkan dan ditarik kembali oleh fans menuju heater. Sebelumnya, humidifier akan memberikan uap panas sehingga tercipta kelembaban yang akan didorong melalui siklus heater.

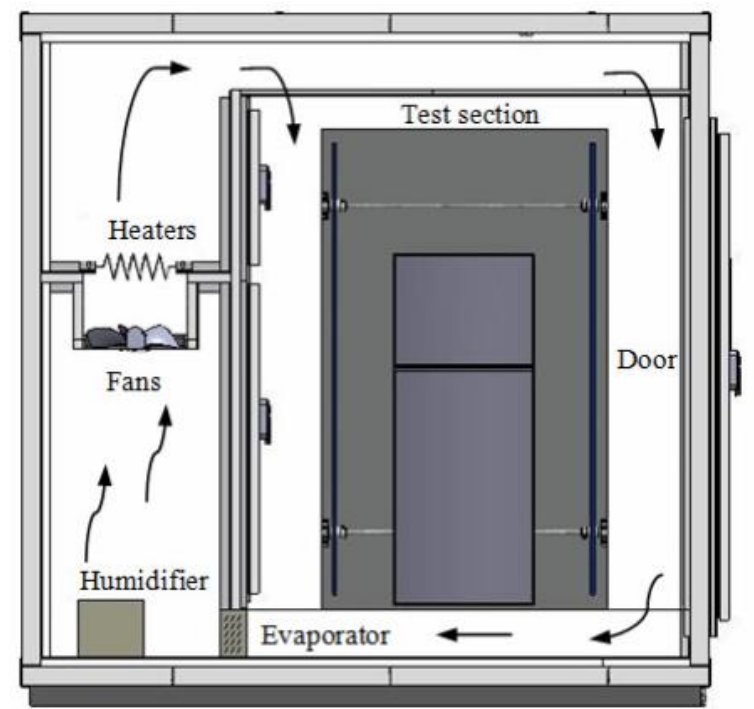

Gambar 1 Aliran udara dan komponen chamber pengujian energi efisiensi lemari pendingin (Hermes dkk, 2012).

Secara matematis, model suatu chamber dengan aktuator tunggal berupa heater dengan kecepatan aliran konstan dapat digambarkan dinamikanya seperti gambar 2 . Terdapat dua transfer energi yang cukup penting terjadi pada suatu chamber yaitu energi panas dari pemanas $\left(Q_{\text {in }}\right)$ dan energi dari ruangan chamber ke lingkungan (Qloss). Oleh karena itu, perubahan suhu didalam chamber $\left(\mathrm{T}_{\text {in }}\right)$ juga tidak terlepas dari suhu pemanas ( $T_{\text {heat}}$ ) dan suhu diluar chamber ( $T_{\text {out }}$ ).

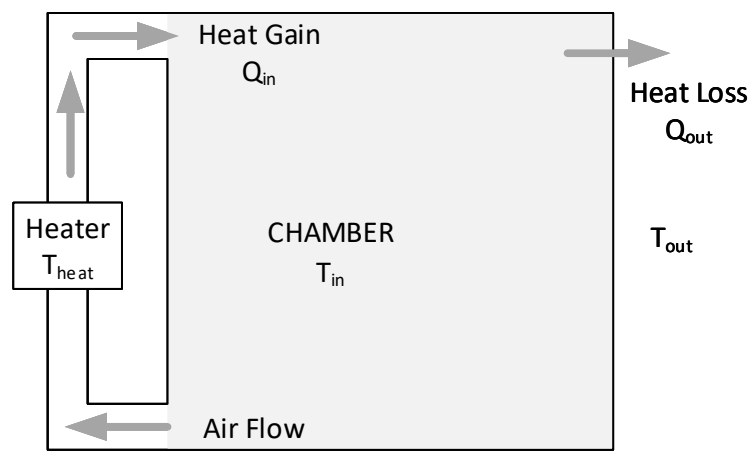

Gambar 2 Dinamika perubahan suhu pada chamber.

Transfer energi pada pemanas terjadi secara konveksi pada massa udara ( $m_{\text {heat}}$ ) yang 
dialirkan dan melalui pemanas. Setiap material memiliki kapasitas panas spesifik /specific heat capacity (Cair), yaitu suatu besaran terukur untuk memanaskan suhu dari suatu zat termasuk udara. Oleh karena itu, suhu udara pada ruang chamber yang dialirkan pada suatu kecepatan konstan akan menjadi lebih panas setelah melalui pemanas apabila suhu pemanas melebihi suhu chamber. Hubungan pemanasan udara pada ruang chamber ditunjukkan pada persamaan (1) (Mathworks,2017).

$$
\frac{d Q_{\text {in }}}{d t}=\frac{d m_{\text {heat }}}{d t} c_{\text {air }}\left(T_{\text {heat }}-T_{\text {in }}\right)
$$

Dengan :

$Q_{\text {in }}=$ Transfer energi panas dari heater (Joule)

$\mathrm{T}_{\text {in }}=$ Suhu chamber $\left({ }^{\circ} \mathrm{C}\right)$

$\mathrm{T}_{\text {heat }}=$ Suhu pemanas $\left({ }^{\circ} \mathrm{C}\right)$

$\mathrm{m}_{\text {heat }}=$ Massa udara pada pemanas $(\mathrm{Kg})$

$\mathrm{C}_{\text {air }}=$ kapasitas panas spesifik udara (kJoule/ $\mathrm{Kg} \mathrm{K}$ )

\subsection{Pengendali PID dengan Metode Pertama Ziegle Nichols.}

Metode pertama Ziegler Nichols dapat digunakan ketika model matematis sistem dapat diturunkan maupun tidak. Secara fakta, aturan dari pengaturan parameter secara Ziegler Nichols dapat digabungkan dengan metode pengaturan terbaik setelah didapatkan nilai parameter awal. Sehingga pengguna tidak perlu menerka nilai awal dari parameter PID(Ogata, 2010).

Hubungan antara sinyal kendali yang dikeluarkan oleh pengendali PID dengan sistem ditunjukkan pada persamaan (2) (Chopra dkk, 2014). Ketiga penguatan $K_{P}, K_{\text {, dan }} K_{D}$ berkaitan dengan error yang dihasilkan dari nilai pengukuran keluaran sistem terhadap nilai acuan.

$$
u(t)=K_{p} e(t)+K_{I} e(t) d t+K_{D} \frac{d e(t)}{d t}
$$

Dengan :

$$
\begin{array}{ll}
u(t)= & \text { Sinya kendali } \\
e(t)= & \text { Sinyal error } \\
K_{P}= & \text { Konstanta proporsional } \\
K_{D}= & \text { Konstanta derivatif } \\
K_{I}= & \text { Konstanta integral } \\
& \text { Menggunakan aturan metode pertama } \\
\text { maka sistem akan diberikan masukan berupa }
\end{array}
$$

nilai step untuk melihat respon dari sistem. Pada umumnya respon dari sistem akan menunjukkan kurva berbentuk S. Kurva $S$ yang dimaksud ditunjukkan pada gambar 3 (Ogata, 2010).

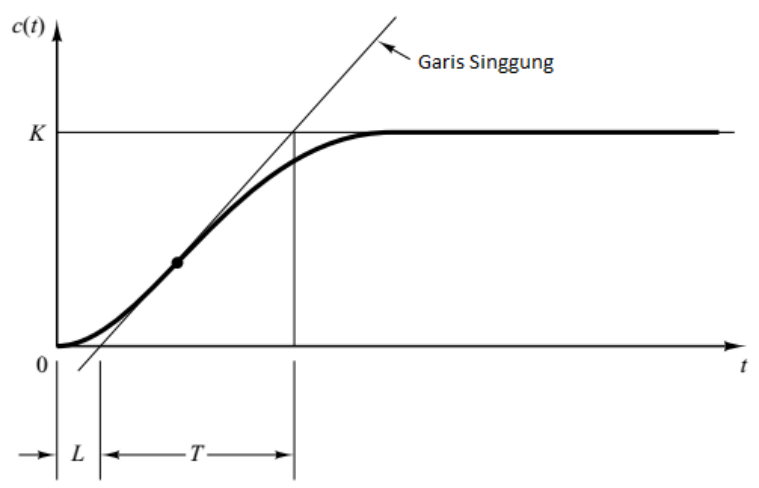

Gambar 3 Respon sistem berbentuk kurva S.

Kurva $S$ yang terbentuk memiliki dua karakteristik konstanta berupa waktu tunda (L) dan konstanta waktu (T). Ketika garis yang bergerak ke atas menyentuh nilai $\mathrm{K}$ dan yang bergerak ke bawah menyentuh sumbu t, maka nilai $T$ dan $L$ dapat dihitung. Selain mendapatkan kedua nilai tersebut, menurut aturan ini maka sistem berpotensi membentuk transfer function sistem dengan waktu tunda seperti ditunjukkan persamaan 3. Nilai $K_{P}, T_{l}$, dan $T_{D}$ berdasarkan aturan pertama Ziegler Nichols dapat dihitung berdasarkan tabel 1 (Ogata, 2010).

$\frac{C(s)}{U(s)}=\frac{K e^{-L s}}{T s+1}$

Dengan :

$C(s)=$ Masukan (input)

$U(s)=$ Keluaran (output)

$\mathrm{K}=$ Nilai antara keadaan awal sampai dengan keadaan tunak

$\mathrm{L}=$ Waktu tunda

$\mathrm{T}=$ Konstanta waktu

Tabel 1 Perhitungan nilai $K_{P}, T_{I}$ dan $T_{D}$ berdasarkan aturan Ziegler Nichols.

\begin{tabular}{cccc}
\hline $\begin{array}{c}\text { Tipe } \\
\text { Pengendali }\end{array}$ & $K_{\boldsymbol{P}}$ & $\boldsymbol{T}_{\boldsymbol{I}}$ & $\boldsymbol{T}_{\boldsymbol{D}}$ \\
\hline $\mathrm{P}$ & $\frac{T}{L}$ & $\infty$ & 0 \\
\hline $\mathrm{PI}$ & $0,9 \frac{T}{L}$ & $\frac{L}{0,3}$ & 0 \\
\hline $\mathrm{PID}$ & $1,2 \frac{T}{L}$ & $2 L$ & $0,5 L$ \\
\hline
\end{tabular}


Nilai $K_{l}$ dan $K_{D}$ dibutuhkan dalam pengimplementasian PID. Terdapat persamaan untuk mengkonversi nilai $T_{\text {l }}$ dan $T_{D}$ kedalam bentuk $K_{I}$ dan $K_{D}$ seperti ditunjukkan pada persamaan 4 dan 5 (Jamal, 2015). Setelah nilai tersebut didapatkan, apabila hasil tanggapan sistem masih belum sesuai bisa diatur dengan mengacu kepada tabel 2 (Korsane dkk, 2014).

$K_{I}=\frac{K_{P}}{T_{I}}$

$K_{D}=\frac{K_{P}}{T_{D}}$

Dengan :

$K_{P}=$ Konstanta proporsional

$K_{D}=$ Konstanta derivatif

$K_{l}=$ Konstanta integral

$T_{I}=$ Waktu integral

$T_{D}=$ Waktu derivatif

Tabel 2 Pengaruh perubahan $\mathrm{K}_{\mathrm{P}}, \mathrm{K}_{\mathrm{I}}$ dan $\mathrm{K}_{\mathrm{D}}$ terhadap respon sistem.

\begin{tabular}{llcl}
\hline $\begin{array}{c}\text { Respon } \\
\text { Simpul } \\
\text { Tertutup }\end{array}$ & Overshoot & $\begin{array}{c}\text { Settling } \\
\text { Time }\end{array}$ & $\begin{array}{c}\text { Kesalahan } \\
\text { Keadaan } \\
\text { Tunak }\end{array}$ \\
\hline $\begin{array}{l}\text { Menambah } \\
\mathrm{K}_{\mathrm{P}}\end{array}$ & Bertambah & $\begin{array}{c}\text { Sedikit } \\
\text { Bertambah }\end{array}$ & Berkurang \\
\hline $\begin{array}{l}\text { Menambah } \\
\mathrm{K}_{\mathrm{I}}\end{array}$ & Bertambah & Bertambah & $\begin{array}{c}\text { Berkurang } \\
\text { Banyak }\end{array}$ \\
\hline $\begin{array}{l}\text { Menambah } \\
\mathrm{K}_{\mathrm{D}}\end{array}$ & Bertambah & Berkurang & $\begin{array}{c}\text { Sedikit } \\
\text { Berubah }\end{array}$ \\
\hline
\end{tabular}

\subsection{Pengendali Logika Fuzzy}

Pengendalian logika fuzzy/ fuzzy logic controller (FLC) banyak digunakan dalam berbagai sistem teknik. Salah satu kelebihan dari pengendali ini adalah tidak diperlukannya model matematis dari sistem yang akan dikendalikan (Lilly, 2010). Struktur pengendali logika fuzzy terdiri dari fuzzifikasi, penalaran fuzzy, basis pengetahuan fuzzy dan defuzifikasi (Ibrahim, 2004).

Proses fuzzifikasi atau transisi perubahan variabel bukan fuzzy kedalam variable fuzzy. Dalam proses ini masukan fuzzy berupa nilai/ crisp dimasukkan kedalam bentuk himpunan. Kemudian dirubah kedalam bentuk bahasa/ linguistik sesuai dengan nama dari himpunan fuzzy yang telah didefinisikan sebelumnya. Himpunan fuzzy dapat dibentuk kedalam fungsi-fungsi keanggotaan yang memiliki berbagai bentuk. Umumnya bentuk dari fungsi keanggotaan berupa segitiga atau trapesium, namun banyak pula jenis lainnya seperti sigmoid, bell ataupun gaussian (Pristianto, 2015).

Selain fungsi keanggotaan, diperlukan operator untuk menghubungkan interseksi antar himpunan. Beberapa jenis operator yang umum digunakan diantaranya adalah AND dan OR. Nilai $\alpha$-predikat pada operator AND diperoleh dengan mengambil nilai keanggotaan terkecil antar elemen pada himpunan-himpunan yang bersangkutan. Untuk operator OR sebaliknya yaitu dengan mengambil nilai keanggotaan terbesar (Fitriadi,2015).

Penelitian ini menggunakan metode defuzifikasi sugeno. Metode sugeno lebih umum dibandingkan dengan metode mamdani. Persamaan untuk nilai tegas keluaran dari sistem fuzzy ini adalah sebagai berikut (Lilly, 2010) :

$$
y^{\text {crisp }}=\frac{\sum_{i=1}^{R} q^{i} \mu_{i}(\underline{x)}}{\sum_{i=1}^{R} \mu_{i}(\underline{x})}
$$

Dengan :

$y^{\text {erisp }}=$ nilai keluaran tegas.

$q^{i}=$ nilai tegas dari setiap aturan

$\mu_{i}=$ nilai bobot dari setiap aturan.

\section{METODE PENELITIAN}

\subsection{Perancangan Ruangan Chamber}

Chamber dirancang dengan beberapa komponen utama seperti ruang chamber, pemanas dan kipas (blower fan). Komponenkomponen tersebut kemudian dirangkai menjadi satu kesatuan seperti ditunjukkan pada gambar 4. Posisi penempatan kipas dan pemanas ada dalam saluran khusus (duct), dimana kipas berada di bawah blower.

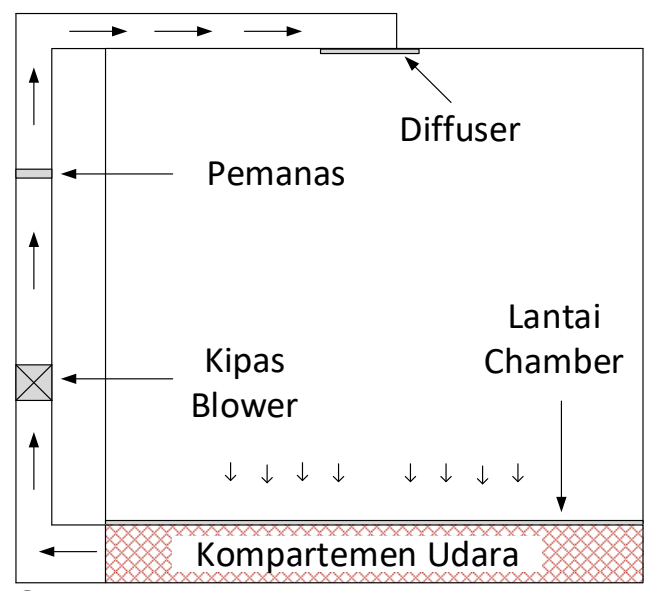

Gambar 4 Posisi komponen chamber. 
Ruang chamber sebagian besar terbuat dari bahan metal memiliki panjang, lebar dan tinggi yang sama yaitu 1,22 meter. Kerangka chamber dibuat dengan kombinasi antara besi siku dan plat strip dengan ketebalan $\pm 2 \mathrm{~mm}$. Bagian selubung chamber memiliki bahan utama yaitu kombinasi seng dan aluminium (zincalum) dengan ketebalan $\pm 0.25 \mathrm{~mm}$. Thermal conductivity dari zincalum ini berkisar dari 114,7 - 125,5 W/m/k, tergantung dari komposisi dan proses pembentukannya (Wikipedia, 2018) Lantai chamber terbuat dari styrofoam dengan ketebalan $\pm 2 \mathrm{~cm}$ dan dilubangi di beberapa bagian. Terdapat diffuser yang ditempatkan di bagian tengah atas ruang tersebut dan berfungsi untuk menyebarkan udara.

Beban berupa sebuah lemari pedingin mini ditempatkan di tengah-tengah chamber. Fungsi dari beban ini adalah memberi gangguan berupa panas dari sistem refrigerant yang akan mengganggu suhu kompartemen chamber. Hal ini untuk menguji ketahanan dari pengendali yang dirancang apakah mampu mengatasi error yang terjadi.

\subsection{Sistem Perangkat Keras}

Blok diagram sistem dan mikrokontroller ditunjukkan pada gambar 5. Mikrokontroller yang digunakan dalam penelitian ini adalah arduino mega 2560. Rangkaian dimmer digunakan untuk mengendalikan tegangan AC $220 \mathrm{~V}$ yang digunakan oleh pemanas sehingga suhu yang dihasilkan dapat bervariasi. Sensor suhu digital yang digunakan adalah DS18B20 yang memiliki akurasi $0.5{ }^{\circ} \mathrm{C}$ dengan akurasi sensor yang dapat diatur dalam 9 sampai 12 bit. Kipas untuk mensirkulasi udara menggunakan jenis DC brushless yang mampu berputar sampai 52000 rpm dengan pengendali ESC (Electronic Speed Controller) yang terhubung ke Arduino.

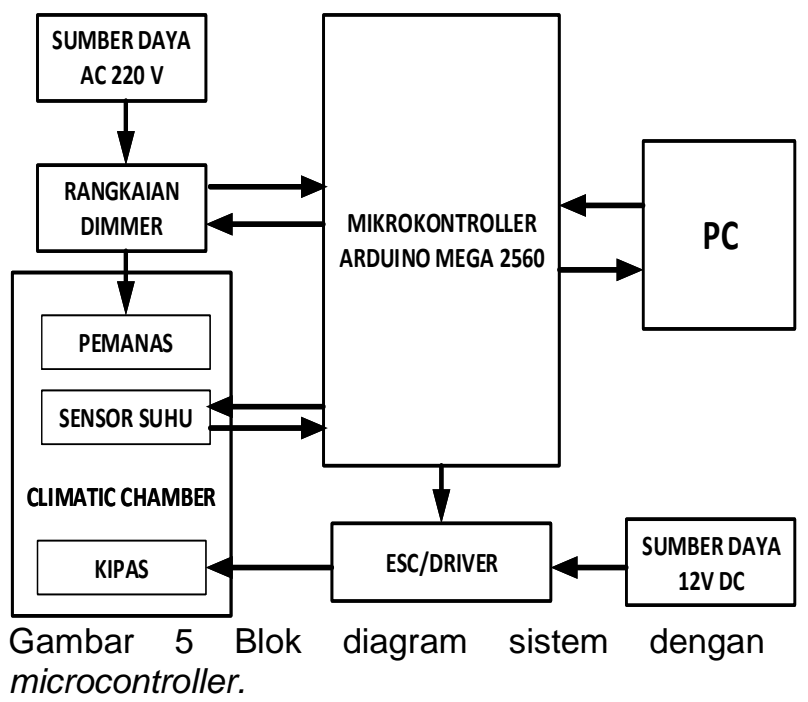

Skematik rangkaian dimmer ditunjukkan pada gambar 6. Terdapat beberapa komponen elektronik pada rangkaian dimmer. Komponen tersebut antara lain berupa IC 4N35 yang berfungsi sebagai zero detector dan IC MOC 3020 optocoupler. Selain itu terdapat dioda untuk penyearah dan TRIAC sebagai saklar untuk tegangan VAC. (forum.arduino.cc, 2016).

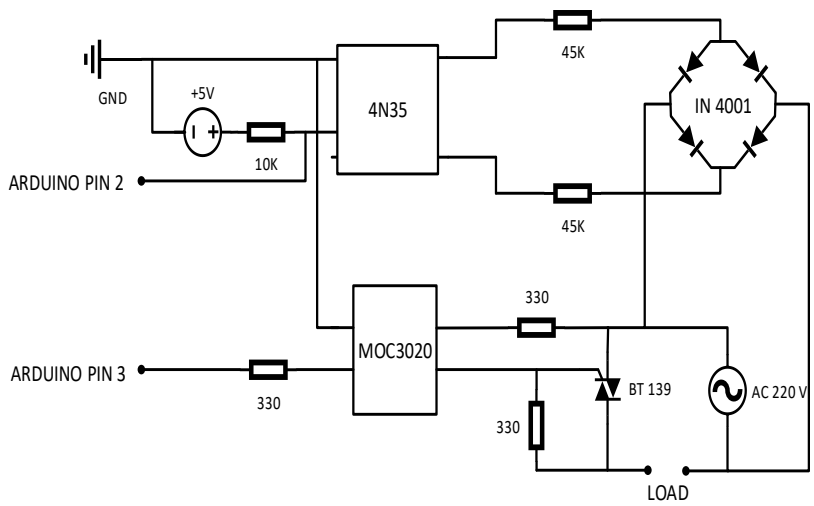

Gambar 6 Skematik rangkaian dimmer.

Nilai penyalaan dimmer pada penelitian ini di petakan (map) melalui algoritma mikrokontroller dengan nilai $0-150$. Nilai 0 berarti tegangan pada beban (LOAD) akan mendekati 0 atau tidak ada tegangan, sedangkan ketika nilai 150 maka tegangan beban akan sama dengan tegangan masukan.

\subsection{Perancangan Pengendali PID}

Masukan step berupa nilai penyalaan 60 dimasukkan pada rangkaian dimmer. Kecepatan kipas blower dijaga konstan. Hasil tanggapan sistem berupa suhu rata-rata dengan masukkan diatas ditunjukkan gambar 7 .

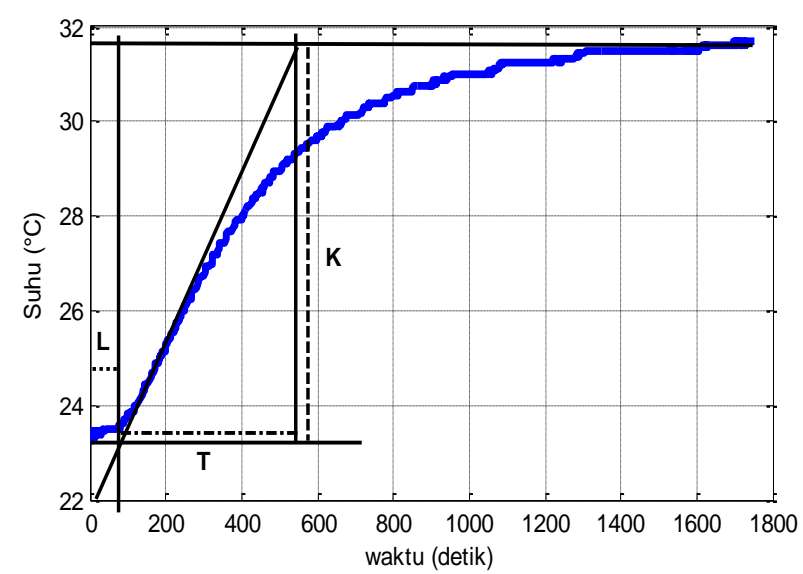

Gambar 7 Tanggapan sistem open loop dengan masukan step.

Berdasarkan gambar 7 tanggapan dari sistem diatas, didapatkan tiga parameter yaitu K, $\mathrm{L}$ dan $\mathrm{T}$. Nilai $\mathrm{K}$ yang didapat adalah sebesar 
8,38, nilai $L$ sebesar 75,27 dan nilai $T$ sebesar 530,53. Menggunakan tabel 1, maka akan didapat nilai $\mathrm{K}_{\mathrm{P}}$ sebesar 8,46, $\mathrm{T}_{\mathrm{I}}=150,54$ dan $\mathrm{T}_{\mathrm{D}}$ $=37,635$. Selain itu, didapat juga nilai $\mathrm{K}_{\mathrm{I}}$ sebesar 0.0562 dan $K_{D}=0,225$.

\subsection{Perancangan Pengendali Fuzzy}

Tahapan perancangan pengendali fuzzy terbagi menjadi tiga yaitu fuzzifikasi, menentukan fungsi implikasi (fuzzy rule) dan defuzzifikasi. Fuzzifikasi adalah pembentukan fungsi keanggotaan dari setiap masukan (input) dan keluaran (output).

\section{- Fungsi keanggotaan input error}

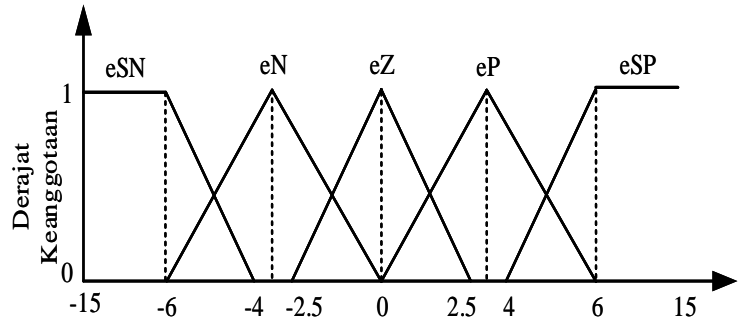

Gambar 8 Fungsi keanggotaan error suhu $\left({ }^{\circ} \mathrm{C}\right)$.

\section{Keterangan :}

a. eSN (error sangat negatif) = keadaan saat suhu jauh dibawah yang diinginkan

b. eN (error negatif) = keadaan saat suhu tidak terlalu jauh dari yang diinginkan

c. eZ (error zero) = keadaan saat suhu sama dengan yang diinginkan

d. eP (error positif) = keadaan saat suhu tidak terlalu jauh melebihi yang diinginkan

e. eSP (error sangat positif) = keadaan saat suhu jauh melebihi yang diinginkan

- Fungsi keanggotaan input delta error

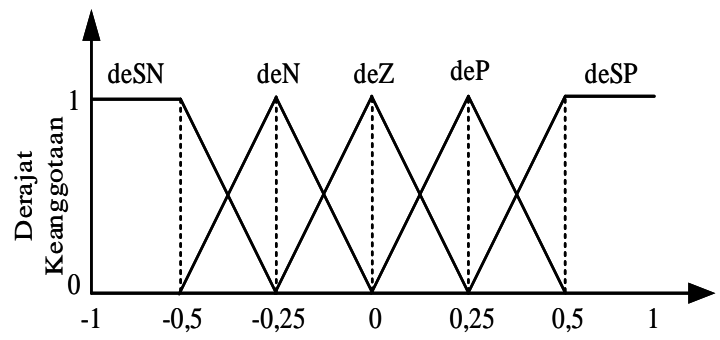

Gambar 9 Fungsi keanggotaan delta error suhu $\left({ }^{\circ} \mathrm{C}\right)$.

\section{Keterangan :}

a. deSN (delta error sangat negatif) = nilai error berkurang dengan cepat

b. deN (delta error negatif) = nilai error berkurang dengan lambat

c. deZ (delta error zero) = nilai error konstan d. deP (delta error positif) = nilai error bertambah dengan lambat

e. deSP (delta error sangat positif) = nilai error bertambah dengan cepat

- Fungsi keanggotaan input delta error

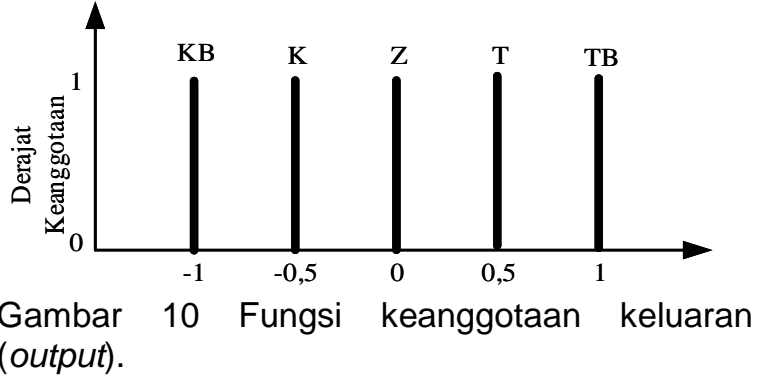

Keterangan :

a. KB (Kurang Banyak) = Nilai PWM dikurangi banyak

b. $\mathrm{K}($ Kurang $)=$ Nilai PWM dikurangi sedikit

c. $Z(z e r o)=$ Nilai PWM nol

d. $T($ Tambah $)=$ Nilai PWM ditambah sedikit

e. TB (Tambah Banyak) = Nilai PWM ditambah banyak

Fuzzy implikasi dibuat pada tahapan ini dengan menggunakan if-then rules. Fungsi tersebut merupakan penghubungan antara kedua input dan output yang sudah dibuat fungsi keanggotaannya. Fungsi implikasi yang telah dibuat di tampilkan dalam tabel 3 FAM (Fuzzy Associative Memories) yang ditunjukkan pada tabel dibawah. Defuzzifikasi pada penelitian ini menggunakan metode sugeno.

Tabel 3 Fuzzy Associative Memories (FEM).

\begin{tabular}{cccccc}
\hline $\begin{array}{l}\text { dError } \\
\text { Etrer }\end{array}$ & deSN & deN & deZ & deP & deSP \\
\hline eSN & KB & KB & KB & K & Z \\
eN & KB & KB & K & Z & T \\
eZ & KB & K & Z & T & TB \\
eP & K & Z & T & TB & TB \\
eSP & Z & T & TB & TB & TB
\end{tabular}

\section{HASIL DAN PEMBAHASAN}

Chamber yang telah dibuat pada penelitian ini ditunjukkan pada gambar 12. Chamber ini memiliki volume maksimum \pm 1584 liter. Untuk pengujian energi efisiensi lemari pendingin, chamber ini dapat menampung lemari pendingin jenis mini dengan ketinggian maksimum $60 \mathrm{~cm}$. 


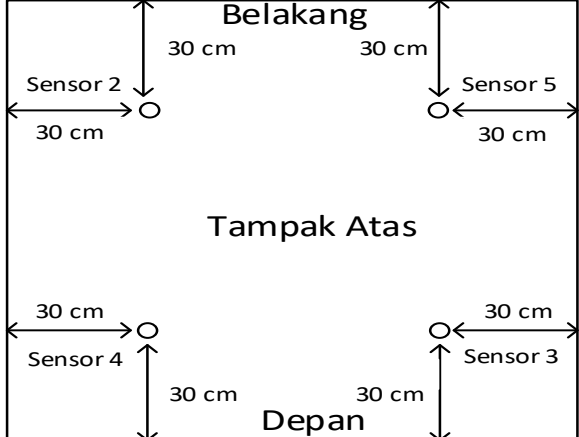

Gambar 11 Posisi sensor pada chamber.

Penelitian ini menggunakan sensor sebanyak 4 buah yang ditempatkan sesuai dengan gambar 11 . Nilai rata-rata sensor digunakan untuk umpan balik ke pengendali.
Ketinggian sensor dari lantai chamber sebesar \pm $55 \mathrm{~cm}$

\subsection{Pengujian Pengendali PID}

Pengendali PID yang telah dirancang menggunakan metode pertama ziegler nichols diuji dengan diberikan suhu acuan sebesar 32 ${ }^{\circ} \mathrm{C}$. Adapun waktu cuplik yang digunakan sebesar 1 detik. Terdapat penyesuaian nilai $K_{P}$, $\mathrm{K}_{\mathrm{I}}$ dan $\mathrm{K}_{\mathrm{D}}$ dari perancangan yaitu $\mathrm{K}_{\mathrm{P}}=7,46, \mathrm{~K}_{\mathrm{I}}=$ 0,0362 dan $K_{D}=0,325$. Respon suhu rata-rata chamber dengan kendali PID ditunjukkan pada gambar 13.
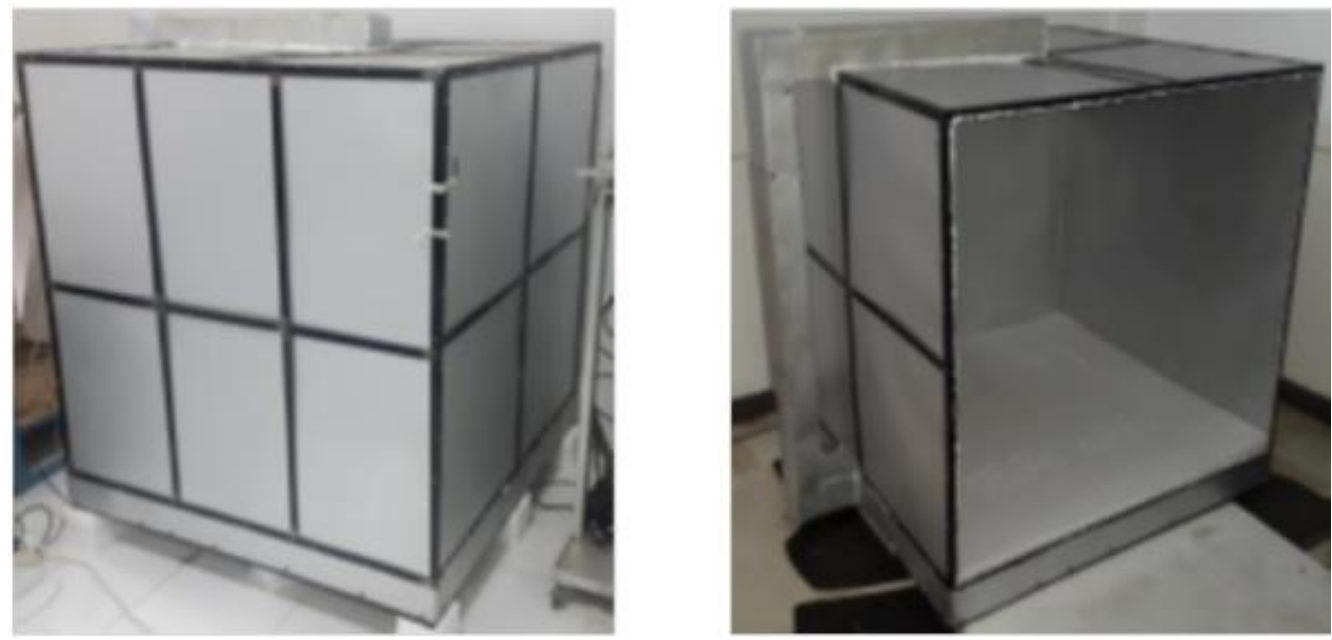

Gambar 12 Chamber dalam keadaan terbuka (kanan) dan tertutup (kiri).

Berdasarkan gambar 13 , suhu rata-rata sistem mampu mencapai keadaan tunak pada waktu 780 detik. Adapun nilai kesalahan saat keadaan tunak (error steady state) yang terjadi masih berada dibawah ambang batas dari standar yaitu $\pm 0.5^{\circ} \mathrm{C}$.

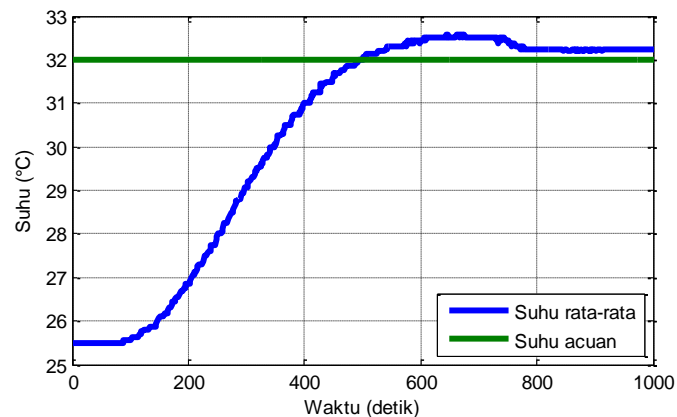

Gambar 13 Tanggapan sistem pada suhu acuan $32{ }^{\circ} \mathrm{C}$ dengan kendali PID.

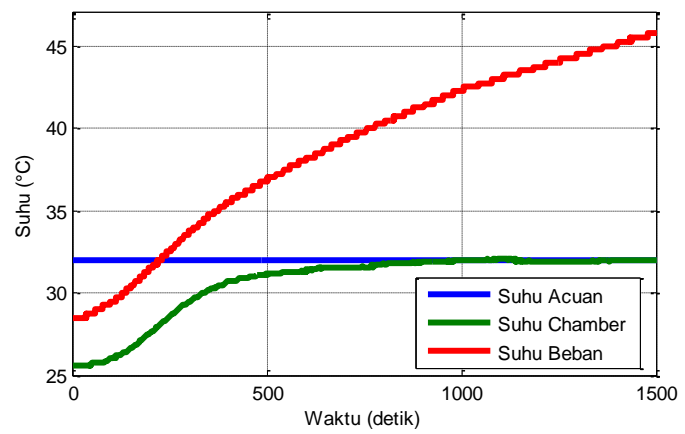

Gambar 14 Suhu rata-rata sistem chamber pengendali PID dengan beban refrigerator.

Berdasarkan gambar 14, sistem chamber dengan kendali PID mampu menahan suhu ratarata di dalam chamber sesuai dengan suhu acuan. Suhu sistem mulai tunak di suhu $32{ }^{\circ} \mathrm{C}$ dalam waktu sekitar 850 detik. Sistem tetap dalam keadaan tunak meskipun suhu beban yang diukur pada permukaan kompresor refrigerator 
tetap naik sampai diatas $45{ }^{\circ} \mathrm{C}$. Adapun error keadaan tunak yang terjadi selama sistem dibebani masih dibawah batas standar.

\subsection{Pengujian Pengendali Fuzzy}

Pengendali fuzzy yang telah dirancang diberikan suhu acuan sebesar $32{ }^{\circ} \mathrm{C}$. Waktu cuplik pembacaan sensor berada di sekitar 1 detik. Hasil pengujian ditunjukkan oleh gambar 15 untuk tanggapan sistem rata-rata sensor.

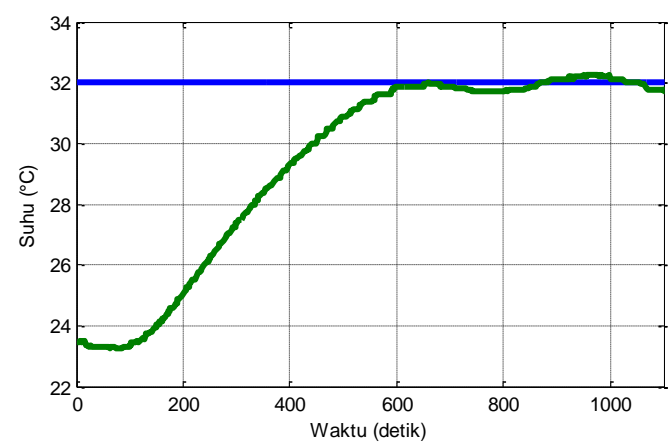

Gambar 15 Tanggapan sistem dengan pengendali fuzzy suhu rata-rata terhadap suhu acuan.

Gambar 15 menunjukkan keluaran sistem dengan menggunakan pengendali fuzzy yang telah dirancang. Garis warna biru merupakan suhu acuan dan garis hijau adalah tanggapan dari sistem. Sistem mencapai suhu yang diinginkan pada waktu sekitar 690 detik. Adapun error yang terjadi masih berada dibawah deviasi maksimum dari suhu acuan $\pm 0,5^{\circ} \mathrm{C}$.

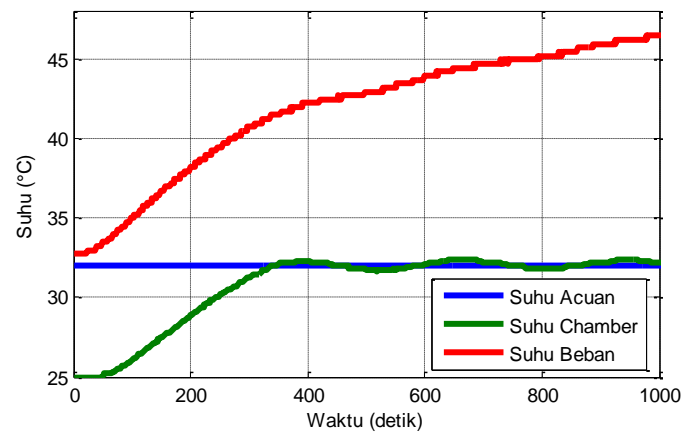

Gambar 16 Suhu rata-rata sistem chamber kendali fuzzy dengan beban refrigerator.

Sistem chamber dengan pengendali fuzzy memiliki respon suhu lebih cepat menuju keadaan tunak meskipun terbebani oleh refrigerator seperti ditunjukkan gambar 16. Waktu yang diperlukan sistem untuk mencapai keadaan tunak berada di sekitar 450 detik. Sama seperti pengendali PID, sistem tetap mampu mempertahankan besar error keadaan dibawah deviasi maksimum $\pm 0,5{ }^{\circ} \mathrm{C}$ dari suhu acuan meskipun suhu beban terus naik diatas $45^{\circ} \mathrm{C}$.

\section{KESIMPULAN}

Kedua pengendali PID dan fuzzy yang telah dirancang sebelumnya mampu membawa suhu chamber ke nilai yang diinginkan yaitu $32^{\circ} \mathrm{C}$. Spesifikasi toleransi yang diizinkan oleh standar yaitu $\pm 0,5^{\circ} \mathrm{C}$ dari suhu acuan dapat dicapai oleh kedua pengendali baik dengan atau tanpa beban. Pengendali PID saat implementasi tanpa beban mampu mencapai keadaan tunak pada waktu 780 detik, sedangkan fuzzy di sekitar 690 detik melalui pembacaan sensor rata-rata. Saat dibebani, pengendali PID mencapai keadaan tunak dalam 850 detik sedangkan fuzzy dalam 450 detik. Dari keduanya didapat bahwa pengendali fuzzy yang di desain mampu memberikan kedaan tunak lebih cepat dari pengendali PID.

\section{UCAPAN TERIMA KASIH}

Puji syukur penulis ucapkan kepada Allah SWT yang telah memberikan rahmat Nya sehingga penulis dapat menyelesaikan penelitian ini. Ucapan terima kasih juga penulis sampaikan kepada Kepala Pusat Penelitian Sistem Mutu dan Teknologi Pengujian - LIPI serta civitas dan rekan-rekan mahasiswa Peminatan Kendali, Program Magister Teknik Elektro - ITB yang telah banyak membantu dan memberikan saran terkait penelitian ini.

\section{DAFTAR PUSTAKA}

Chopra, V., Singla, S.K., Dewan, L., (2014): Comparative Analysis of Tuning a PID Controller using Intelligent Methods, Journal Acta Polytechnica Hungarica.

Fitriadi, Riky. (2015) : Perancangan dan Implementasi Sistem Penggerak dan Kendali Kecepatan Motor BLDC dengan Pengaturan PWM Berbasis Logika Fuzzy. Unpublished master's thesis, Institut Teknologi Bandung, Bandung, Indonesia.

Forum. Arduino. (2016). How to controll A.C. 230 $\checkmark$ fan speed with arduino, http://forum. arduino.cc/index.php?topic=132141.0, diakses pada 13 Desember 2016.

Globalspec, (2016). Environtmental Test Chamber Information, http://www.globals pec.com/learnmore/labware_test_measur ement/product_material_testing/ēnvironm 
ental test chambers, diakses pada 30 November 2016.

Hermes, C., Melo, C., Knabben, F.T. (2012) :Alternative Energy Test Method for Frost-Free Refrigerators and Freezers, :IRACC.

Ibrahim, A. M. (2004) : Fuzzy Logic for Embeded System Application, Newnes, USA:

International Electrotechnical Comission (IEC). (2015). IEC 62552-1, Household refrigerating appliances - Characteristics and test methods, Switzerland: IEC.

Jamal, Z. (2015) : Implementasi Kendali PID Penalaan Ziegler-Nichols Menggunakan Mikrokontroller :Jurnal Informatika IBI.

Korsane, D.T., Yadav, V., Raut, K.H. (2014) : PID Tunning Rules for First Order Plus Time Delay System, :IJIREEICE

Lilly, John. H. (2010) : Fuzzy Control and Identification, John Wiley \& Sons, USA:
Mathworks. (2017). Model a Dynamic System, https://www.mathworks.com/help/simulink /gs/define-system.html, diakses pada 19 Februari 2017.

Ogata, Katsuhiko. (2010) : Modern Control Engineering Fifth Edition, Prentice Hall, USA:

Pristianto, E.J. (2015) : Perancangan dan Implementasi Kendali AGC GMC992LP5E dengan Logika Fuzzy pada Sistem Penerima Radar Pulsa. Unpublished master's thesis, Institut Teknologi Bandung, Bandung, Indonesia.

UNDP. (2016). Barriers Removal to the cost effective development of Energy Efficiency Standards and Labelling, http://www.id.undp.org/content/indonesia/ en/home/operations/projects/environment _and_energy/barriers-removal-to-thecost-effective-development-of--energyef.html, diakses pada 21 Juli 2016.

Wikipedia. (2018). Zincaluminium, https://en.wiki pedia.org/wiki/Zinc_aluminium, diakses pada tanggal 09 April 2018. 
